\title{
KWESTIA TOŻSAMOŚCI WŚRÓD RUSKICH ELIT POLITYCZNYCH W GALICJI
}

\author{
Marian Mudryj \\ Uniwersytet Lwowski im. I. Franki
}

\section{ABSTRACT \\ THE QUESTION OF IDENTITY AMONG THE RUTHENIAN POLITICAL ELITES IN GALICIA}

The article refers to the necessity of a scientific understanding of the concept of "political elites" in relation to the Ukrainian movement in Galicia in the $19^{\text {th }}$ century. The author considers the concepts of identity which existed among the Ruthenian-Ukrainian elites in Austrian Galicia. These were: Austrophilism, Polonophilism, Russophilism and Ukrainophilism. The author argues that the only coherent criterion for determining the Galician-Ruthenian elites was the ability of certain groups and individuals to conceptualize the dimension of nationality, and also to deploy activities on behalf of the national community. The creation of the Galician-Ruthenian elites was a part of the wider modernization processes experienced by the Galician Ruthenians. These elites were forced to solve not only questions of national identity, but also ideological dilemmas that had arisen on the verge of tradition and innovation, conservatism and democracy. Therefore, the formation of Ruthenian political elites was related not only to the support of the existing environments' influence on the government and society, but also to designing completely new units of public activity. The representatives of the new intelligentsia became the main figures in these cells, which consisted mainly of the clergy, peasants and unrich tradesmen.

Key words: Galicia, Ruthenian (Ukrainian) community, the political elite, identity.

Słowa kluczowe: Galicja, społeczność ruska (ukraińska), elity polityczne, tożsamość.

Świat polityki Rusini galicyjscy odkrywali dla siebie stopniowo, poruszając się w swoich rozumowaniach od negatywnego definiowania polityki jako takiej (bo uważali ją za nielojalną wobec dynastii oraz kojarzyli z polskim ruchem, a w szczególności z polską tradycją powstańczą) do rozumienia polityki jako rzeczywistego instrumentu służącego realizacji postępu społecznego, czyli jako sposób na przemianę 
w kierunku emancypacji społecznej i narodowej. Na ogół historycy uważają, że przejście ruskiego/ukraińskiego ruchu w Galicji od etapu kulturalno-oświatowego do stadium politycznego rozwoju odbyło się w kontekście i pod decydującym wpływem rewolucyjnych wydarzeń z 1848 roku$^{1}$. Wątpię, że to stwierdzenie da się podważyć. A jednak należy wziąć pod uwagę, że rewolucja sama przez się żadnej kwestii nie rozwiązuje. Ona tylko wyraźnie ujawnia problemy w stosunkach między władzą a społeczeństwem, lecz ich rozwiązanie mimo wszystko przypada już na okres porewolucyjny i przebiega na płaszczyźnie stosunków władz państwowych i nielicznego grona działaczy społecznych, próbujących mówić w imieniu całego narodu, a tak naprawdę mówiących przede wszystkim we własnym imieniu.

Zdefiniowanie ruskiego/ukraińskiego środowiska politycznego w Galicji, czyli elit politycznych, okazuje się bardzo skomplikowane. Kwestia ta powiązana jest bowiem z narodowymi, ale również z socjalnymi i kulturalnymi doświadczeniami społeczności. Dla przykładu, walka o status społeczny duchowieństwa greckokatolickiego, kwestia alfabetu (cyrylica czy łacinka), praktyki czytelnicze oraz sposób postrzegania świata przez księży w pierwszej połowie XIX wieku, ale również światopogląd pierwszych pokoleń rusko-ukraińskiej inteligencji - to wszystko stanowiło obszar polityczny życia publicznego, podobnie jak walka partyjna, już na początku $\mathrm{XX}$ wieku. Nawet pojawienie się na przełomie XIX i XX stulecia pierwszego pokolenia ukraińskich zawodowych polityków nie oznaczało, że osoby te zupełnie zerwały ze swoimi dotychczasowymi zajęciami (przeważnie działalnością nauczycielską lub adwokaturą). Rzeczywiście polityka zaistniała dla nich jako priorytet, ale o jej sensie nie decydowało wówczas pragnienie sprawowania władzy jako próba samorealizacji.

W ukraińskiej i polskiej historiografii nie brakuje ogólnych prac historyczno-politologicznych o syntetycznym charakterze, ale publikacji, w których obiektem badawczym byłaby wprost ruska/ukraińska elita polityczna w Galicji, właściwie nie ma. Tymczasem materiałów do tego tematu jest wiele. Są one rozproszone między innymi w pracach biograficznych oraz opracowaniach z zakresu dziejów ukraińskiej inteligencji albo ukraińskiego ruchu narodowego ${ }^{2}$. Sporo materiałów i wątków na

1 J. Kozik, Ukraiński ruch narodowy w Galicji w latach 1830-1848, Kraków 1973; ide m, Między reakcja a rewolucją. Studia z dziejów ukraińskiego ruchu narodowego w Galicji w latach 1848-1849, Warszawa-Kraków 1975; O. Турій, Греко-католицька Церква і революиія 1848-1849 рр. у Галичині [w:] Rok 1848. Wiosna Ludów w Galicji, red. W. Wic, Kraków 1999, s. 72-91; I. Мон ол аті й, Інші свої. Політична участь етнічних акторів пізньогабсбурзьких Галичини і Буковини, Івано-Франківськ 2012, s. 182.

2 W latach 1993 i 1994 Instytut Badań Historycznych stworzony w tym czasie na Uniwersytecie Lwowskim im. Iwana Franki realizował projekt pt. Ukraińskie odrodzenie narodowe w Galicji XIX i na początku XX w. Analiza porównawcza składu społecznego grup patriotycznych. O celach i wynikach tego projektu zob. Я. Грицак, Українське національне відродження в Галичині XIX-nочатку XX cm. Порівняльний аналіз соціального складу патріотичних груn, „Krakowskie Zeszyty Ukrainoznawcze” 1996-1997, t. 5-6, s. 277-285. Historyk Swiatosław Pachołkiw rozpatruje z kolei ukraińskie elity w Galicji w kontekście kształtowania się narodowej inteligencji oraz rozwoju samoorganizacji społecznej. Zob. С. Пахолків, Українська інтелітениія у Габсбурзькій Галичині. Освічена верства й емансипаиія націï, Львів 2014 (niemieckojęzyczne wydanie: S. Pacholkiv, Emanzipation durch Bildung. Entwicklung und gesellschaftliche Rolle der ukrainischen Intelligenz im habsburgischen Galizien (1890 1914), München 2002). 
ten temat możemy znaleźć w opracowaniach poświęconych ukraińskim reprezentantom w Sejmie Krajowym i Radzie Państwa ${ }^{3}$. Trzeba jednak przeprowadzić badania nad całościowym obrazem ruskiej elity politycznej. Niniejszy artykuł to krok w tym kierunku $\mathrm{u}^{4}$. W zasadzie jedynym jak dotychczas opracowaniem, którego autor próbował rozważyć działania przedstawicieli ukraińskiego ruchu w kategoriach politycznej elity, jest monografia Bohdana Janyszyna ${ }^{5}$. Ponadto niektóre punkty orientacyjne oraz nowe podejścia metodologiczne w prowadzeniu badań nad elitami galicyjskimi zaproponował badacz Iwan Monołatij z Iwano-Frankiwska w pracy dotyczącej wzajemnego oddziaływania na siebie różnych grup etnicznych i narodowych na obszarze zachodnioukraińskim ${ }^{6}$ oraz krakowski historyk Łukasz Tomasz Sroka w monografii na temat składu i działalności lwowskiej Rady Miejskiej w latach 1870-19147.

\section{POJĘCIE „RUSKIE/UKRAIŃSKIE ELITY POLITYCZNE”}

Zazwyczaj elitą polityczną nazywa się grupę osób wyróżniającą się spośród politycznego środowiska wyższym stopniem rozwoju konkretnych wartości

3 Np. O. Arkusza, Ukraińskie przedstawicielstwo w sejmie galicyjskim [w:] Ukraińskie tradycje parlamentarne, XIX-XXI wiek, red. J. Moklak, Kraków 2006, s. 13-57; S. Pijaj, Postowie ruscy w parlamencie wiedeńskim [w:] Ukraińskie tradycje..., s. 95-126; H. Binder, Ukraińskie przedstawicielstwo $w$ austriackiej Izbie Postów, 1879-1918 [w:] Ukraińskie tradycje..., s. 127-162; I. Чорновол, 199 депутатів Галииького сейму, Львів 2010. Na związek kwestii politycznych i językowo-oświatowych na przykładzie działań ruskich/ukraińskich posłów sejmowych oraz w kontekście kształtowania się tożsamości galicyjskich Ukraińców wskazuje J. Moklak, $W$ walce o tożsamość Ukraińców. Zagadnienia języka wykładowego w szkołach ludowych i średnich w pracach galicyjskiego Sejmu Krajowego 1866-1892, Kraków 2004; idem, Hatyczyna contra Galicja. Ukraińskie szkolnictwo średnie i wyższe w debatach Sejmu Krajowego galicyjskiego 1907-1914, Kraków 2013.

4 Niniejszy artykuł opiera się na zdaniu, że ukształtowanie się nowoczesnego ruskiego (a w perspektywie - ukraińskiego) środowiska politycznego Galicji było jednym z rezultatów austriackiej/ habsburskiej modernizacji kraju. A ponieważ austriacka modernizacja dotyczyła przede wszystkim zakresu rządów cesarskich (przez wprowadzenie nowych form współdziałania władzy i społeczeństwa) oraz organizacji biurokracji (na temat austriackiej „modernizacji przez biurokratyzację” zob. В. Гайндль, Модернізація та теорії модернізації. Приклад габсбурзької бюрократії, „Україна модерна" 1996, ч. 1, s. 89-100), to w badaniach ruskich elit politycznych w Galicji istotne są zwłaszcza następujące zadania: a) wyjaśnić, jak wewnątrz świata cesarskiej polityki kształtowały się wąskie grupy pośrednie, które na różne sposoby starały się upolityczniać etniczność i próbowały mówić w imieniu większej, narodowej wspólnoty; b) ustalić, w jaki sposób światopogląd i tożsamość konkretnej osoby determinowały podejmowanie konkretnych decyzji administracyjnych; i wreszcie c) wyjaśnić, w jaki sposób w Galicji odbywało się współdziałanie między urzędnikiem a działaczem społecznym. Wymienionych tu problemów badawczych nie da się rozwinąć w jednym artykule, należy je więc raczej traktować jako wytyczne dla poszukiwań badawczych na przyszłość.

5 Б. Янишин, Українська міська політична еліта в Галичині та народовський рух останньої третини XIX cm. Становлення та інституційний розвиток, Київ 2008.

6 I. Монолатій, Разом, але майже окремо. Взаємодія етнополітичних акторів на західноукраӥнських землях у 1867-1914 рр., Івано-Франківськ 2010.

7 Ł.T. Sroka, Rada Miejska we Lwowie w okresie autonomii galicyjskiej 1870-1914. Studium o elicie władzy, Kraków 2012. 
politycznych. Elita polityczna składa się z elity rządzącej i counter-elity znajdującej się w opozycji do grupy rządzącej. Termin „elita” wprowadzili na początku XX wie$\mathrm{ku}$ francuski badacz Georges Sorel i włoski uczony Vilfredo Pareto, chociaż idea podziału społeczeństwa na wyższe i niższe warstwy istniała od dawna. Niemiecki socjolog Robert Michels połączył kwestie powstania i funkcjonowania politycznych elit z działalnością partii politycznych, rządzonych przez mniejszość. To on sformułował ,żelazne prawo oligarchii”, według którego powstanie w trakcie społecznego postępu skomplikowanych organizacyjnych struktur prowadzi do kształtowania elity. Ponieważ kierowania tymi strukturami nie mogą się podjąć wszyscy członkowie społeczeństwa, to z niego wyodrębnia się polityczna elita, z czasem wymykająca się spod kontroli obywateli i podporządkowująca politykę własnym interesom.

Na podstawie analizy europejskich praktyk politycznych (a monarchia Habsburgów była jednym z głównych elementów europejskiej przestrzeni politycznej) można stwierdzać, że w XIX wieku zaszły znaczące przemiany w rozumieniu polityki i kształtowaniu elit politycznych. Do połowy stulecia przeważał tak zwany system gildyjny. Miał on cechy pozytywne (zrównoważone i przemyślane polityczne decyzje, znikomy stopień ryzyka przy ich podjęciu, wysoka przewidywalność polityki, niskie niebezpieczeństwo wewnętrznych konfliktów), jak i negatywne (tendencja do biurokratyzacji, organizacyjnej rutyny i dogmatyzmu, kultywowanie masowego konformizmu). Bez dopełnienia przez zastosowanie konkurencyjnych mechanizmów system ten prowadził do degradacji politycznej elity, jej oderwania od potrzeb narodu i przekształcenia w uprzywilejowaną kastę. W drugiej połowie XIX wieku w związku z kształtowaniem środowiska fachowych polityków - upowszechnił się tak zwany system entrepreneurski (czyli - mówiąc inaczej - managerski). On również miał cechy pozytywne (takie jak otwartość, szerokie możliwości na wejście do elity dla przedstawicieli różnych grup społecznych, niewielka liczba formalnych wymogów dla kandydatów, wysoka konkurencja doboru, ostra rywalizacja o stanowiska kierownicze, pierwszoplanowe znaczenie osobistych cech, indywidualna aktywność, umiejętność uzyskiwania wsparcia szerokiej publiczności) i negatywne (powodował w polityce duże ryzyko i niefachowość, niską przewidywalność, skłonność do dbania o efektowność działań i populizmu ponad miarę), a jednak odzwierciedlał bliskość epoki polityki masowej.

Owe rozważania teoretyczne dotyczące pochodzenia elit politycznych można zastosować również wobec sytuacji Rusinów/Ukraińców w Galicji. Jednocześnie trzeba wziąć pod uwagę, że sytuacja ta miała sporo cech specyficznych. Rusini w tym czasie nie posiadali rozwiniętej warstwy ziemiańskiej ani burżuazyjnej. Kształtowanie ruskich elit politycznych w Galicji zależało więc najpierw od postępów modernizacji społecznej, czyli od demokratyzacji życia publicznego, przejawiającej się przede wszystkim w emancypacji warstwy chłopskiej i tworzeniu inteligencji. W XIX wieku faktycznie nie było u władzy ruskich elit politycznych. Nieliczni Rusini zasiadający na stanowiskach (oczywiście, nie najwyższych) w krajowej administracji prawie nigdy do początku XX wieku nie występowali publicznie w obronie interesów ruskiej wspólnoty narodowej. Właściwie ruskie elity polityczne rozwijały się w opozycji do władz. Oto najistotniejsze pytania, na które ruscy aktywiści musieli 
szukać odpowiedzi i które w końcu najlepiej charakteryzowały samą ruską elitę polityczną: a) jaki był zakres lojalności i opozycyjności wobec władz państwowych i krajowych?; b) jakie były osiągnięcia w zakresie szukania jedności dla wspólnoty narodowej (czyli próby przezwyciężenia granicy austriacko-rosyjskiej)?; c) jakie były stosunki z polskimi elitami w kraju i na forum wiedeńskim?

Gdzie szukać ruskich/ukraińskich elit politycznych w Galicji? Biorąc pod uwagę, że galicyjscy Rusini wchodzili w nowoczesność bez rozwiniętej struktury społecznej, że w ciałach rządowych mieli bardzo nieliczną reprezentację i że w XIX wieku rozwój ruchu ruskiego/ukraińskiego odbywał się pionowo (nie był on statyczny, ciągle znajdował się w trakcie kształtowania), widzimy bardzo różne ośrodki, instytucje, a nawet środowiska ówczesnych intelektualistów lub działaczy kulturalnych, występujące jako centra wpływu politycznego i uprawiania polityki przez Rusinów. Warunkowo można podzielić je na następujące grupy:

1. Greckokatolicki konsystorz metropolitalny we Lwowie oraz towarzystwa narodowo-kulturalne i oświatowe, działające pod cerkiewnym patronatem: Instytut Stauropigialny, Greckokatolickie Seminarium Generalne, Narodnyj Dim, a nawet Wydział Teologiczny Uniwersytetu Lwowskiego ${ }^{8}$.

2. Austriackie państwowe instytucje przedstawicielskie oraz instytucje krajowego samorządu w Galicji: galicyjski Sejm Stanowy, galicyjski Sejm Krajowy, ruskie/ukraińskie przedstawicielstwo (tzw. klub) w parlamencie wiedeńskim.

3. Polityczne towarzystwa i partie: Hołowna Ruśka Rada, Ruska/Russkaja Rada, Narodna Rada, Rusko-Ukraińska Partia Radykalna, Ukraińska Partia Narodowo-Demokratyczna, Ukraińska Partia Socjal-Demokratyczna, Russka Partia Ludowa, Związek Chrześcijańsko-Społeczny i in.

4. Redakcje czasopism łączące utalentowanych publicystów i kształtujące opinię publiczną: „Zoria Hałyćka” („Зоря Галицька”, 1848-1857), „Słowo” („Слово”, 1861-1887), „Diło” („Діло”, 1880-1939), „Narod” („Народ”, 1890-1895), „Haliczanin” („Галичининъ”, 1893-1913), „Rusłan” („Руслан", 1897-1914) i in.

W przypadku ruskiej/ukraińskiej społeczności w Galicji trudno mówić o jednolitej, skonsolidowanej elicie politycznej. W zasadzie lepiej mówić o elitach politycznych, w liczbie mnogiej. Były to niewielkie grupy i środowiska, które bardzo rozmaicie rozumiały „ruskość” oraz sposoby jej prezentacji. Możemy stwierdzić (zwłaszcza z późniejszej, historycznej perspektywy), że taka mnogość czyniła galicyjskich Rusinów słabymi wobec polskiego środowiska politycznego; lecz jednocześnie należy rozumieć, że dla większości przedstawicieli tych elit bycie politykiem miało najpierw wymiar personalny. Osoby te równocześnie starały się odpowiedzieć na pytanie, jaka

8 Współczesny znawca dziejów Wydziału Teologicznego Uniwersytetu Lwowskiego ks. Józef Wołczański pisze: „Zgodnie z dyrektywami ideologicznymi józefinizmu austriackie uniwersyteckie fakultety teologiczne - w tym również lwowski - nie prowadziły badań naukowych, ale przygotowywały oddanych państwu, operatywnych biurokratycznie urzędników państwowych" (Ks. J. Wołczański, Wydziat Teologiczny Uniwersytetu Lwowskiego w latach 1661-1939 [w:] Universitati Leopoliensi. Trecentesimum quinquagesimum anniversarium suae fundationis celebranti. In memoriam, red. W. Lohman, Kraków 2011, s. 111). 
jest ich własna tożsamość, oraz próbowały występować w imieniu szerokiej abstrakcyjnej wspólnoty, którą wyobrażały sobie głównie za pośrednictwem literatury i historii. Ruskie środowiska polityczne cechowała zatem w tym czasie duża płynność, brak ukształtowanej struktury organizacyjnej i sprecyzowanych poglądów, dlatego decydującą rolę w nich odgrywały właśnie pojedyncze osobistości, niezdradzające zresztą przez długi czas swoich pomysłów i przekonań. Kiedy mowa o nastrojach ruskiej wspólnoty w Galicji, to właśnie wspomniane osoby stawały się punktami orientacyjnymi dla polityków polskich i austriackich w podejmowaniu decyzji lub wyborze politycznego partnera w celu zawarcia umów.

Chronologicznie pierwszym pokoleniem galicyjsko-ruskich polityków w okresie „długiego" XIX wieku byli przedstawiciele zamkniętych korporatywnych instytucji (np. Instytutu Stauropigialnego oraz świętojurskiej hierarchii greckokatolickiej), opierających się na tradycji i często się nią zasłaniających. Personifikacja polityki w tym środowisku w żaden sposób nie była akcentowana. Najbardziej jaskrawymi przedstawicielami tego środowiska stali się greckokatoliccy metropolici. Instytut Stauropigialny zaś jednoczył intelektualną i bogatszą część lwowskich Rusinów. $Z$ rozwojem publicznej przestrzeni - a możliwości takie powstały dopiero w związku $\mathrm{z}$ reformami konstytucyjnymi z lat 60 . XIX wieku - ukształtowało się środowisko rusko-ukraińskich działaczy społecznych, a ich aktywność miała znaczenie polityczne. Wśród tych osób byli: Jakiw Hołowaćkyj/Jakow Gołowackij, Bohdan Didyćkij, Julijan Ławrowśkyj, bracia Wołodymyr i Ołeksandr Barwinścy, Julijan Romanczuk, Kost' Łewyćkyj, Jewhen Ołesnyćkyj, Iwan Franko. Oni wszyscy zostali politykami dzięki intelektualnym/twórczym zdolnościom i społecznej aktywności. Było jeszcze jedno (prawie nieznane dotychczas nawet dla historyków) środowisko ruskich polityków w Galicji - w istocie urzędników - które wolało nie deklarować swoich poglądów, lecz pełniło ważną funkcję pośrednika między władzą a działaczami społecznymi. Wśród takich osób można wymienić Hryhorija Szaszkewycza, Kornyła Mandyczewśkiego czy Damiana Sawczaka.

\section{MIĘDZY CERKWIA A CESARZEM. AUSTRORUSIŃSTWO JAKO TOŻSAMOŚĆ RUSKICH ELIT W GALICJI W PIERWSZEJ POŁOWIE XIX WIEKU}

Do połowy XIX stulecia ruskie elity polityczne w Galicji były mocno powiązane z greckokatolicką hierarchią cerkiewną. Cerkiew i władze austriackie zmuszały ruską ludność do przekształcenia swojego dotychczasowego podświadomego przywiązania do rodzimego kraju w ideę narodowości, do uświadomienia sobie więzi z etniczną wspólnotą, która ma swoją odrębną historię oraz własne potrzeby polityczne i kulturalne. Za świadomą podstawę ówczesnej politycznej tożsamości ruskiej elity należy uznać austrorusiństwo. Był to pogląd, właściwy duchowieństwu greckokatolickiemu (a za jego pośrednictwem również chłopstwu), według którego austriacki dwór cesarski za pośrednictwem Cerkwi greckokatolickiej miał pełnić funkcję 
patrona galicyjskich Rusinów, a Cerkiew z kolei miała być jedynym reprezentantem ich interesów. Jeśli spojrzeć z historycznej perspektywy, to austrorusiństwo odzwierciedlało pewien etap w rozwoju ruskiej narodowości w Galicji, kiedy jeszcze nie zadawano pytania o możliwość współistnienia ruskiej ludności także poza granicami imperium Habsburgów.

Austrorusiństwo - jako pewien wariant tożsamości i zarazem postawa polityczna Rusinów galicyjskich - było rezultatem przeprowadzenia terezjańsko-józefińskich reform z lat 70 i 80 . XVIII wieku. Reformy te wyraźnie zmieniły położenie duchowieństwa unickiego na lepsze. W momencie utworzenia Galicji wiejski ksiądz unicki, zarówno jeśli chodzi o uposażenie, jak i o rozwój duchowy oraz wykształcenie, zasadniczo nie różnił się od chłopa. Udostępniwszy Rusinom (a byli to przeważnie synowie duchownych) drogę do edukacji, i to prowadzoną w języku ojczystym, zrównawszy w obliczu prawa Cerkiew unicką z Kościołem rzymskokatolickim oraz zabezpieczywszy w minimalnym zakresie materialną podstawę do bytu dla duchownych, reformy oświeceniowe Habsburgów sprzyjały integracji Cerkwi unickiej z systemem państwowo-politycznym monarchii oraz przekształceniu tej Cerkwi w jeden z instrumentów sprawowania władzy przez państwo austriackie. Dzięki temu, że władze austriackie szukały przeciwwagi dla wpływów polskich w Galicji, Cerkiew greckokatolicka została wyposażona w nową strukturę organizacyjną - w 1808 roku odnowiono greckokatolicką metropolię halicką. Metropolici - Antin Anhełłowycz (1808-1814), Mychajło Łewyćkyj (1816-1858), Hryhorij Jachymowycz (18601863), Spyrydon Łytwynowycz (1863-1869), Josyf Sembratowycz (1870-1882) ${ }^{9}$ - nie tylko przyjęli austrorusiństwo za podstawę własnego światopoglądu politycznego, lecz również uczynili z niego program polityczny dla całej Cerkwi. Tylko Sylwestr Sembratowycz (1885-1898) oraz Andrzej Szeptycki (1900-1944) potrafili tak kierować Cerkwią, aby nie rościła ona sobie prawa do bycia politycznym i kulturalnym monopolistą na ruskiej scenie politycznej. Innymi słowy, w czasach obu metropolitów Cerkiew stała się jedną z wielu konkurencyjnych sił politycznych, a nie jedyną, jak to było wcześniej ${ }^{10}$.

Austrorusiństwo (a zarazem i sama ruska elita polityczna w Galicji) ukształtowało się w dużej mierze dzięki próbie, niepozbawionej zresztą emocjonalnego ładunku, przeciwstawienia austriackiej teraźniejszości polskiemu panowaniu w przeszłości. Nie byłoby jednak prawdą stwierdzenie, że podstawę działania dla greckokatolickiej hierarchii w tym czasie stanowiły jedynie polityczne kalkulacje. Przez długi czas bowiem ani metropolici, ani parafialne duchowieństwo greckokatolickie nie myślały o sobie w kategoriach politycznej elity. Można powiedzieć, że w duchu

9 Szerzej na temat działalności pierwszych metropolitów greckokatolickich zob. S. Nabywaniec, Antoni Angetlowicz i Michat Lewicki, pierwsi greckokatoliccy metropolici halicko-lwowscy, „Resovia sacra. Studia Teologiczno-Filozoficzne Diecezji Rzeszowskiej” 1996, t. 3, s. 139-157.

$10 \mathrm{Na}$ temat Cerkwi greckokatolickiej w kontekście ukraińskiego ruchu narodowego zob. J.-P. Himka, Religion and Nationality in Western Ukraine. The Greek Catholic Church and the Ruthenian National Movement in Galicia 1867-1900, Montreal-Kingston-London-Ithaca 1999. 
monarchicznego paternalizmu nazywali siebie „ojcami narodu" ${ }^{11}$. Publicysta orientacji ukrainofilskiej trafnie oceniał Rzeczpospolitą Obojga Narodów w jej ostatnich latach istnienia jako „bezduszny organizm państwowy”, na którego ruinach, w obrębie monarchii Habsburgów, znaleźli się galicyjscy Rusini. Nikt z Rusinów, twierdził publicysta, nie miał wtedy powodu, aby zatęsknić za przeszłością, ponieważ „w tym blasku, w tym szumie, w tych rozkoszach zapomnieli syci o głodnych, bankietujący o pracujących, pełnoprawni o nieposiadających praw" 12 . Spotkanie Rusinów z Austrią wychodziło naprzeciw ich oczekiwaniom. Reformy Austriaków wyjątkowo udanie sprzęgły się zatem z nastrojami ludności ruskiej, a przede wszystkim duchowieństwa greckokatolickiego.

Instytucją, która zjednoczyła ruską elitę w Galicji na zasadach austrorusiństwa i historycznej „ruskości”, był Instytut Stauropigialny we Lwowie, utworzony w 1788 roku na bazie bractwa cerkiewnego o tej samej nazwie, które działało od końca XVI wieku, broniąc interesów ruskiej ludności. Według cesarskiego patentu z 1787 roku wszystkie bractwa kościelne miały zostać zlikwidowane, w tym jednak przypadku zrobiono wyjątek, przekształcając bractwo w instytut. Kompromis ten nadał zatem wagi politycznej ambicjom ówczesnej ruskiej elity, kształtującej się na rumowisku po dawnej Rzeczypospolitej. Tytułowanie członków Instytutu Stauropigialnego w dokumentach rządu austriackiego „przeorami narodu greckokatolickiego” było świadectwem uznania Rusinów za samodzielny naród, aczkolwiek w przednowoczesnym rozumieniu tego słowa. Dla ówczesnej ruskiej elity ten - ukierunkowany przez władze - typ tożsamości okazał się możliwy do przyjęcia. W XIX wieku Instytut Stauropigialny liczył około 50 członków. Na ich tożsamość wskazywał statut (zatwierdzony przez władze dopiero w 1868 r.), w którym znalazł się wymóg, że członkiem Instytutu może zostać „każdy Rusin, który jest katolikiem greckiego obrządku, posiada pełnię praw obywatelskich, reprezentuje sobą nienaganne zachowanie moralne i cieszy się dobrą reputacją”, a także ma wysoki status społeczny, aby „dzięki swojej edukacji naukowej, wiedzy albo majątkowi mógł być pożyteczny dla Instytutu”"13.

$\mathrm{Z}$ austrorusiństwem wiązała się koncepcja „galicyjsko-ruskiego narodu”, która zdobyła popularność wśród hierarchów Cerkwi greckokatolickiej. Patrząc z historycznej perspektywy, można ocenić, że ostatecznie nie przybrała ona ideologicznego wymiaru, lecz przez długi okres (aż do lat 70. XIX w.) stanowiła główny komponent tożsamości kleru greckokatolickiego, zwłaszcza wyższej hierarchii cerkiewnej. Dokumentem najlepiej odzwierciedlającym ową tożsamość jest list-memoriał metropolity Josyfa Sembratowycza do wydziału towarzystwa politycznego „Ruska Rada”

11 To trafnie zauważyła B. Wój tow icz-Huber,,,Ojcowienarodu”. Duchowieństwo greckokatolickie w ruchu narodowym Rusinów galicyjskich (1867-1918), Warszawa 2008.

12 [В. Барвінський], Въ стольтнй роковины вступленя на австрійскій престолъ йғсаря Іосифа II (1780-1880). Отчитъ Володимира Барвъньского, выголоченый на вечерг дня 17 (29) листопада 1880, Львів 1880, s. 5-6.

$13 \mathrm{Na}$ temat struktury, składu, platformy ideologicznej oraz działalności lwowskiego Instytutu Stauropigialnego zob. I. Орлевич, Ставропігійський інститут у Львові (кінеиь XVIII - 60-i pp. XIX cm.), Львів 2001 [2-ге вид.]; О. Киричук, Львівський Ставропігійський інститут у громадському житті Галичини другої половини ХIX - початку XX ст., Львів 2001. 
(przesłany na ręce prezesa towarzystwa Teofila Pawlikowa) z 28 grudnia 1870 roku, pod wymownym tytułem: „Myśli dla zgodnego postępowania galicyjskich Rusinów w sprawach swoich narodowych" (Мысли для согласного поступованя галицкихъ Русиновъ въ дголахъ своихъ народныхъ). List miał przekonać „polityków” (rusofilskiego i ukrainofilskiego nurtu), że powinni oni podporządkować się Cerkwi, zrezygnować z poszukiwań tożsamości poza granicami austriackiej Galicji. Autorem memoriału był prawdopodobnie Mychajło Małynowśkyj - ówczesny doradca konsystorza metropolitalnego i prawie jedyna w tym czasie osoba w środowisku świętojurskim, która potrafiłaby skonceptualizować nastroje i pragnienia „partii staroruskiej”14. Należy tu jednak mieć świadomość tego, że osoby pragnące kierować się interesami „galicyjsko-ruskiej narodowości” nie myślały w kategoriach etnicznych. Swoją przywódczą rolę pragnęły sprawować w imię swojego, wąskiego prowincjalizmu albo też ze względów polityczno-taktycznych, zarysowując w ten sposób granice swojej zwierzchności.

\section{MIĘDZY POLSKĄ A ROSJĄ: ORIENTACJE NARODOWO-POLITYCZNE WŚRÓD RUSKICH ELIT POLITYCZNYCH W GALICJI W DRUGIEJ POŁOWIE XIX WIEKU}

Mimo bardzo różnych tłumaczeń dotyczących pochodzenia i natury nowoczesnych narodów historycy przyznają, że XIX wiek był okresem przełomowym, ponieważ wtedy wspólnoty polityczne, społeczne i etniczne zyskały nową jakośćc ${ }^{15}$. To wówczas zakorzeniło się przeświadczenie, że fundamentem narodu jest świadomość narodowa (tożsamość), za której pośrednictwem naród nabywa właściwej dla siebie formy istnienia. Narodowa świadomość (tożsamość) to przede wszystkim ujęcie siebie jako wspólnoty narodowej, jako narodu-nacji. Osiągnięta w taki sposób ,świadomość narodowa" stanowi syntezę obiektywnych i subiektywnych przejawów, które przetwarzały naród ze stanu potencjalnego w stan rzeczywisty. W sytuacji Rusinów/ Ukraińców kształtowanie się nowoczesnej świadomości narodowej nie było prostym procesem, odbywało się ono przez odgraniczenie się od silniejszych - polskiej i rosyjskiej - tożsamości i jednocześnie przez współdziałanie z nimi ${ }^{16}$. Taki internarodowy

14 Tekst memoriału znajduje się w: Центральний державний історичний архів України м. Львів, ф. 196: Політичне товариство „Руська рада”, оп. 1, спр. 18, арк. 1-4. Zob. też I. Химка, „Апологія” Михайла Малиновського. До історії кризи у греко-католицькій церкві 1882 року $i$ характеристики поглядів „святоюриів”, „Записки Наукового товариства імені Шевченка” 1993, t. 225: Праці Історично-філософської секиії, s. 365-392; М. Мудрий, Австрорусинство в Галичині. Спроба окреслення проблеми, „Вісник Львівського університету. Серія історична” 2000, вип. 35-36, s. 571-604.

15 Najpełniejszy przegląd współczesnych interpretacji nacji i nacjonalizmu zob. Г. Касьянов, теорії нації та націоналізму, Київ 1999.

16 O ukraińskim ruchu w Galicji jako współdziałaniu kilku orientacji pisał J.-P. Himka, The Construction of Nationality in Galician Rus'. Icarian Flights in Almost All Directions [w:] Intellectuals 
kontekst procesu narodotwórczego rodził (zwłaszcza w początkowej fazie) liczne formy przejściowe, które przejawiały się równoczesnym współistnieniem kilku lojalności oraz występowaniem wieloszczeblowych tożsamości.

Pod wpływem politycznych realiów poszukujące swojej tożsamości elity ruskie w połowie XIX wieku coraz częściej zaczęły wychodzić poza granice Galicji. Na jakiś czas w ich świadomości zetknęły się dwie perspektywy - polska i rosyjska. Jednoczesne wyodrębnienie się z systemu polsko-rosyjskich stosunków oraz wpisanie się weń okazało się dla ruskiej/ukraińskiej elity intelektualnej i politycznej w Galicji trudnym wyzwaniem. Wyzwanie to polegało na potrzebie zrozumienia swojej podmiotowości narodowej, czyli bycia kimś, posiadania określonej tożsamości, i zarazem zaaprobowaniu faktu, że w pewnym sensie jest się politycznym przedmiotem, czyli należało zrozumieć siebie jako wartość, na którą skierowana jest także uwaga z zewnątrz. Każda z wymienionych orientacji narodowo-politycznych - polonofilstwo i rusofilstwo („,moskalofilstwo”) - była próbą utrzymania przez ruskie elity polityczne w Galicji swoistej równowagi między tradycją a nowatorstwem. W obu przypadkach chodziło o przeszłość oraz o odzyskanie sposobu jej wykorzystania w przyszłości. Zetknięcie się propolskiej i prorosyjskiej perspektywy skutkowało licznymi rozłamami i w ten sposób stwarzało podstawę dla rozwoju nurtu ukrainofilskiego.

Argumenty zwolenników propolskiej orientacji zostały odzwierciedlone w tekstach, które powstały w środowisku Soboru Ruskiego z 1848 roku, oraz w przemówieniach tak zwanych Rusinów polskiej narodowości w galicyjskim Sejmie Krajowym z lat 60. XIX wieku ${ }^{17}$. Polonofilstwo zasadzało się przede wszystkim na antytezie do centralistyczno-biurokratycznego systemu rządów austriackich oraz do polsko-ruskiego konfliktu w Galicji. To nie był nurt jednolity. Główny podział wewnątrz niego przebiegał między przedstawicielami „polskiego” segmentu, przeważającego ilościowo, a grupą „rusko-ukraińską”. Pierwsi patrzyli na Rusinów jak na terytorialną, językową, kulturalną i obrządkową odmianę polskiego narodu, a drudzy akcentowali etniczną odrębność Rusinów, aczkolwiek widzieli perspektywę dla ich narodowo-kulturalnego rozwoju, tyle że w granicach polskiego obszaru intelektualnego i politycznego. Nie wyobrażali sobie oni istnienia ruskiej narodowości ograniczonej jedynie do greckokatolickiego kleru i włościaństwa, nalegali więc na włączenie w rusko-ukraiński proces narodowotwórczy także świeckiej inteligencji i liberalnej

and the Articulation of the Nation, eds. R.G. Suny, M.D. Kennedy, Ann Arbor (Mich.) 1999, s. 109164. Kwestia ruskich elit politycznych w kontekście narodowo-politycznych orientacji (,partia czysto ruska”, „partia polsko-ruska”, „partia austriacko-ruska”, „partia rosyjsko-ruska”) po raz pierwszy występuje w źródłach historycznych z okresu Wiosny Ludów. Zob. B. Podoliński, Stowo przestrogi [1848], вид. Ф. Стеблій, „Записки Наукового товариства імені Шевченка” (Львів) 1994, т. 228: Прачі Історично-філософської секиії, s. 444-462.

17 Dokładniej o środowisku Rusinów narodowości polskiej zob. М. Мудрий, Ідеологія чи світогляд? До питання про теоретичні засади Руського Собору 1848 року, „Вісник Львівського університету. Серія історична" 2009, вип. 44, s. 75-106; М. Mudryj, Formacja gente Rutheni, natione Poloni w XIX-wiecznej Galicji a pojęcie ojczyzny [w:] Formuly patriotyzmu w Europie Wschodniej i Środkowej od nowożytności do wspótczesności, red. A. Nowak, A.A. Zięba, Kraków 2009, s. 285298; A. Świątek, Gente Rutheni, natione Poloni. Z dziejów Rusinów narodowości polskiej w Galicji, Kraków 2014. 
szlachty. Tylko taka kombinacja społeczna, jak uważali, mogła zabezpieczyć rozwój ruskiej narodowości na postępowych zasadach liberalnych i być gwarancją obrony przed zagrożeniem ze strony kursu klerykalno-konserwatywnego.

W latach 60., 70. i 80. XIX wieku lustrzanym odzwierciedleniem polonofilskiego nurtu wśród przywódców galicyjskich Rusinów stało się rusofilstwo („moskalofilstwo") ${ }^{18}$. Rusofile zaprzeczali przynależności galicyjskich Rusinów do kulturalno-politycznej przestrzeni dawnej Rzeczypospolitej Obojga Narodów i akcentowali ich tożsamość w granicach obszaru ogólnoruskiego. Przynależność do tego obszaru galicyjskich Rusinów miejscowi rusofile wyjaśniali wspólną, zakorzenioną w historii Rusi Kijowskiej i Księstwa Halicko-Wołyńskiego tradycją, uczestnictwem pochodzących z Ukrainy („Małorusi”) osób w tworzeniu rosyjskiego państwa i kultury, oraz wspólną społeczną i językowo-kulturalną niedoskonałością projektowanego narodu ukraińskiego. Głównym bodźcem do ukształtowania się w Galicji rusofilskiego nurtu było rozczarowanie skutkami rewolucji 1848 roku, a w szczególności przekształceniem galicyjskiej prowincji w autonomiczny kraj zdominowany przez Polaków. Światopoglądowo-politycznym manifestem rusofilów stał się artykuł Iwana Naumowicza pt. Poglad w przyszłość (Поглядъ въ будучность), zamieszczony w sierpniu 1866 roku we lwowskiej gazecie „Słowo" literacką, kościelną i narodową łączność galicyjskich Rusinów z całym „ruskim światem". Taka postawa wychodziła naprzeciw wcześniejszym próbom galicyjskich Rusinów, ograniczającym się do poszukiwania swojej narodowo-politycznej tożsamości w obrębie terytorium monarchii Habsburgów. Rusofilstwo w Galicji cechowało się przede wszystkim dążeniem do zachowania tradycyjnej „ruskości” oraz postawą antypolską. Jego zwolennicy chcieli znaleźć dla galicyjskich Rusinów mocniejszą od polskiej przestrzeń narodową, a tą miała być Rosja.

\section{LWÓW CZY KIJÓW? RYWALIZACJA O CENTRUM DLA UKRAIŃSKIEGO RUCHU NA PRZEŁOMIE XIX I XX WIEKU}

Do połowy XIX stulecia austriacko-rosyjska granica w świadomości galicyjskich Rusinów nie była problemem politycznym. W istocie, stała się nim wtedy, kiedy za pośrednictwem historiografii, upolityczniania historii, ideologii politycznej oraz

18 А.В. Вендланд, Русофіли Галичини. Українські консерватори між Австрією та Росією, 1848-1915, пер. 3 нім. Х. Назаркевич, наук. ред. М. Мудрий, Львів 2015 (niemieckojęzyczne wydanie: A.V. Wendland, Die Russophilen in Galizien. Ukrainische Konservative zwischen Österreich und Rußland, 1848-1915, Wien 2001); О. Сухий, Від русофільства до москвофільства (російський чинник у громадській думці та суспільно-політичному житті галицьких українців у ХІХ столітті), Львів 2003; W. Os adczy, Święta Ruś. Rozwój i oddziaływanie idei prawosławia w Galicji, Lublin 2007; Г. Сіромська, Народний Дім у Львові: від старорусинства до русофільства (середина XIX початок XX cm.), Львів 2014.

19 [І. Наумович] Одинъ именемъ многихъ, Отъ Львова. Поглядъ въ будучность, „Слово” 1866, nr 59 z 27 VII (8 VIII). 
ukorzenienia się idei narodowości zyskała znaczenie jako przeszkoda do osiągnięcia narodowej jedności. W tym czasie granica austriacko-rosyjska zdecydowanie większe znaczenie polityczne miała dla Polaków. W pewnym sensie kwestię jedności narodowej ruskich mieszkańców Galicji i Ukrainy w galicyjskim dyskursie narodowo-politycznym aktualizowali polonofile. Jedność ziem ukraińskich z Polską uważali oni za niezbędny warunek przeciwdziałania wpływom rosyjskim i niemieckim. Właśnie ze względu na nalegania polonofilów (np. Julijana Ławrowśkiego) Hołowna Ruśka Rada dodała do programowej odezwy z 10 maja 1848 roku stwierdzenie o przynależności pod względem etniczno-językowym galicyjskich Rusinów do 15-milionowego „wielkiego ruskiego narodu” ${ }^{20}$. Po upływie pewnego czasu do próby „przezwyciężenia" austriacko-rosyjskiej granicy dołączyli się również rusofile, lecz ich intencje były zupełnie inne - pragnęli oni utwierdzić ogólną ruską (russka) jedność, kierując ją przeciw wpływom polskim i niemieckim.

Twórcami nowoczesnej ukraińskiej tożsamości w Galicji stali się tak zwani narodowcy - społeczny nurt kulturalny i polityczny, który rozwijał się od lat 60. do lat 90. XIX wieku i wyraźnie zaakcentował ukrainofilską orientację. Historia tego ruchu odzwierciedlała włączenie się do życia społeczno-politycznego kolejnego po Wiośnie Ludów pokolenia ruskiej inteligencji. Początkowo wyrazicielką nurtu ukrainofilów była młodzież gimnazjalna i studencka; nieco później, w latach 80.-90. XIX stulecia, objęła ona przewodnictwo w ukraińskim ruchu narodowym, prowadząc go aż do rozpadu monarchii habsburskiej. Mimo że wśród ukraińskich narodowców przewagę mieli przedstawiciele świeckiej inteligencji, to głównym źródłem dla kształtowania się inteligencji orientacji ukrainofilskiej w dalszym ciągu pozostawało duchowieństwo greckokatolickie. Według obliczeń historyków około $2 / 3$ przedstawicieli środowiska narodowców pochodziło z rodzin duchownych. Wykształcenie wyższe miało aż 92\% przywódców tego ruchu (ponad połowa z nich była absolwentami Uniwersytetu Lwowskiego). O wysokim oświatowym poziomie narodowców świadczy też to, że prawie $1 / 3$ aktywnych przedstawicieli ruchu posiadała stopień doktorski ${ }^{21}$.

Intelektualna historia ukrainofilów w Galicji była związana $\mathrm{z}$ utwierdzeniem nowoczesnej idei narodowej. Rozwój (albo, według ówczesnych wyobrażeń, „odrodzenie") tej idei uważali oni za główny wymóg i potrzebę chwili. Narodowcy wyraźnie deklarowali odrębność „rusko-ukraińskiego” narodu od Polaków i Rosjan, bronili idei etnokulturowej i narodowej jedności Ukraińców w Imperium Rosyjskim oraz monarchii Habsburgów - na terytorium od Kaukazu do Karpat ${ }^{22}$. Jako nurt liberalny wskazywali oni na potrzebę zabezpieczenia naturalnego prawa człowieka do wolności, lecz widzieli ją w granicach narodowego systemu wartości. Ideolodzy ruchu

20 Оิтозва до руского народу, „Зоря Галицка” 1848, nr 1 z 15 V. O roli J. Ławrowśkiego w przygotowaniu tekstu odezwy zob. [О. Терлецький], Галицько-руське письменство 1848-1865 рр. на тлї тогочасних суспільно-полїтичних змагань галиџько-руської інтелїгениії. Недокінчена праџя Д-ра Остапа Терлещького, переднє слово І. Франко, Львів 1903, s. 7-8.

21 Szerzej zob. Б. Янишин, op. cit.

22 Na temat zakorzenienia w austriackiej Galicji idei ukraińskiej narodowej jedności zob. I. Райківськи й, Ідея української національної єдності в громадському житті Галичини ХІХ століття, Івано-Франківськ 2012. 
narodowców wyszli poza zasięg konfesyjnych wyobrażeń o istocie narodu i stworzyli świecką wersję tego pojęcia. Konserwatywnie nastawione starsze pokolenie ruskiej inteligencji w Galicji postrzegało idee narodowców jako nieuzasadniony radykalizm - porzucenie staroruskich wartości na rzecz słabej ich zdaniem idei ukraińskiej. W porównaniu z narodowcami rusofile („moskalofile”) przyznawali kulturalną odrębność mieszkańcom obszaru „małoruskiego”, lecz nie widzieli w nich cech odrębnego narodu. To pytanie zostawiali otwarte na przyszłość dla historyków i filologów. Konflikt między rusofilami a narodowcami pogłębiały dyskusje dotyczące pisowni: przedstawiciele „staroruskiej partii” bronili etymologicznej („historycznej”) pisowni, bardzo ostro krytykując wykorzystywaną przez narodowców pisownię fonetyczną („kuliszówkę”).

Polityczny sukces narodowców (ukrainofilów) można wyjaśnić przede wszystkim ich nowoczesnym światopoglądem i dużą aktywnością. Umiejętnie odczytywali oni potrzeby nowej epoki - polityki opartej na masach - i byli w stanie zaproponować nowatorskie środki oddziaływania na społeczeństwo i na władzę. Narodowcy stworzyli w Galicji rozbudowaną sieć instytucji narodowych, zapoczątkowali wieczory literackie (najpierw ku czci Tarasa Szewczenki) oraz wiece ludowe (pierwsze takie masowe zebranie odbyło się we Lwowie w 1880 r.). Nie bali się również zapożyczeń od swoich oponentów. W galicyjsko-ruskiej przestrzeni politycznej narodowcy jako pierwsi zrozumieli, że tożsamość to nieustanny ruch. Ruch, który da się poprowadzić nie tylko dzięki pogodzeniu przeszłości z teraźniejszością (do czego ograniczali się w swoich projektach polonofile i rusofile), ale także poprzez zarysowanie wizji przyszłości. W swoich wypowiedziach na temat rozdzielenia przez granicę austriacko-rosyjską ludności ukraińskiej narodowcy opierali się na dziełach literackich i historiograficznych powstałych na Ukrainie Naddnieprzańskiej (autorstwa Tarasa Szewczenki, Pantełejmona Kulisza, Mykoły Kostomarowa i in.). Szczególnie ważnym dla narodowców źródłem narodowej tożsamości galicyjskich Rusinów był mit kozackiej Ukrainy i kult Szewczenki. Stosunkowo luźne odnoszenie się do przeszłości pozwalało im na taktyczne układanie się z sąsiadami. W zależności od sytuacji sojusznikami stawali się zatem dla nich: przedstawiciele polskich środowisk politycznych, rusofile czy w końcu władze austriackie. Ten styl prowadzenia polityki stał się ważnym elementem tożsamości elity politycznej ukształtowanej w środowisku narodowców.

Wzrost wpływów narodowców od schyłku lat 70. XIX wieku był związany z włączeniem się w działalność społeczno-polityczną nowych liderów: Julijana Romanczuka, Kostia Łewyćkiego oraz - szczególnie - braci Wołodymyra i Ołeksandra Barwinśkich. Podstawowym zagadnieniem dla narodowców było umiejscowienie się w politycznym życiu Rusinów galicyjskich i Galicji. Wykorzystując polityczne i ideologiczne porażki „starej partii”, która przyczyniła się do ideologicznego rozwoju nurtu rusofilskiego, narodowcy w wyborach do Sejmu Krajowego w 1883 roku po raz pierwszy zdobyli własne przedstawicielstwo w galicyjskim parlamencie i wkrótce przejęli stery ukraińskiej polityki narodowej w kraju. Po wydaniu $u k a z u$ emskiego (1876 r.), który istotnie ograniczył używanie języka ukraińskiego w Imperium Rosyjskim, nawiązanie współpracy z galicyjskimi ukrainofilami stało się bardzo ważne 
dla ukraińskich działaczy nad Dnieprem. Liderzy kijowskiej „Starej Hromady” Wołodymyr Antonowycz i Ołeksandr Konyśkyj tworzyli plany dotyczące przeniesienia do Galicji centrum ruchu ukraińskiego. Razem z galicyjskimi narodowcami wzięli oni udział w przygotowaniu „nowej ery” - ukraińsko-austriacko-polskiej ugody z 1890 roku.

„Nowa era” istotnie wzmocniła pozycje ukrainofilów w Galicji i faktycznie przyczyniła się do zwycięstwa ukraińskiej tożsamości wśród ludności ruskiej w Galicji²3. Stronnictwa polityczne o nieukraińskiej orientacji od tego momentu zeszły na margines sceny politycznej. Rdzeń politycznej walki (a w praktyce - konkurencji elit politycznych) przemieścił się do środka proukraińskiego obozu. To tu odbywały się ostre dyskusje na temat równowagi między interesami ukraińskiej wspólnoty etnicznej a potrzebami socjalnymi ludności. Narodowym demokratom (byłym narodowcom) udało się, można tak to określić, „ujednolicić” narodowe uczucia ukraińskiej ludności w Galicji, a także nasycić emocjami rozporządzenia partyjne. Według słów historyka Iwana Łysiaka-Rudnyćkiego, na przełomie XIX i XX stulecia w ukraińskim społeczeństwie w Galicji ukształtował się dwupartyjny system: „narodowi demokraci mieli odczuwalną przewagę, radykałowie pozostawali wobec nich w ciągłej opozycji" ${ }^{24}$. Pojawiały się też głosy konserwatystów (najpierw cerkiewnych hierarchów i przedstawicieli ruchu chrześcijańsko-społecznego), próbujących wstrzymać zaostrzenie ukraińsko-polskich stosunków, lecz ich zdanie już mało kto brał pod uwagę. Po zdobyciu politycznych wpływów ukraińscy narodowi demokraci niespodziewanie dla siebie napotkali na nowe wyzwanie: jak teoretyczny koncept „Wielkiej Ukrainy" przekształcić z płaszczyzny wyobrażenia na algorytm działań praktycznych. Ów problem został rozwiązany przez Mychajła Hruszewśkiego - historyka, który w wyniku ukraińsko-austriacko-polskiego porozumienia został w 1894 roku profesorem Uniwersytetu Lwowskiego. Uczony aktywnie włączył się do świata galicyjskiej polityki, domagając się u miejscowych działaczy bezwzględnego podporządkowania się interesom ukraińskiej polityki widzianej z kijowskiej perspektywy. Stworzona we Lwowie przez Hruszewśkiego historyczna szkoła nie tylko była środowiskiem ukraińskich naukowców, ale również stała się społeczno-kulturalnym i politycznym fenomenem ${ }^{25}$.

23 O tym, jak ugoda z 1890 r. zmieniła ukraińskie środowisko polityczne w Galicji, zob. I. Чopновол, Польсько-украӥнська угода 1890-1894 pp., Львів 2000; D. Maciak, Próba porozumienia polsko-ukraińskiego w Galicji w latach 1888-1895, Warszawa 2006; О. Аркуша, „Нова ера” [w:] Енциклопедія історії України, т. 7, Київ 2010, s. 427-430.

24 І. Лисяк-Рудницький, Украӥнці в Галичині під австрійським пануванням [w:] idem, Icторичні есе, упоряд. Я. Грицак, т. 1, Київ 1994, s. 438 (thum. za pol. wyd.: I. Łysiak-Rudnycki, Ukraincy w Galicji pod panowaniem austriackim [w:] idem, Między historia a polityka, red. nauk. G. Hryciuk, thum. M. Buchalik et al., Wrocław 2012, s. 335).

${ }_{25}$ Szerzej zob. Ł. Adamski, Nacjonalista postępowy. Mychajło Hruszewski i jego poglady na Polskę i Polaków, Warszawa 2011; С. Плохій, Великий переділ. Незвичайна історія Михайла Грушевського, Київ 2011; В. Тельвак, В. Педич, Львівська історична школа Михайла Грушевського, Львів 2016. 


\section{RUSKIE ELITY POLITYCZNE W GALICJI MIĘDZY ARYSTOKRATYCZNA A DEMOKRATYCZNĄ FORMĄ RZĄDÓW}

Dla pierwszych pokoleń ruskich polityków w Galicji orientacja na Wiedeń nie podlegała dyskusji, na dodatek była połączona z iluzorycznymi marzeniami o możliwości osiągnięcia takiego statusu, jakiego nie udało się uzyskać w czasach Rzeczypospolitej Obojga Narodów. W istocie żadnych innych wzorców (oprócz szlacheckich z okresu dawnej Polski) aktywni politycznie Rusini wtedy - pod koniec XVIII i w pierwszych dekadach XIX wieku - sobie nie wyobrażali. Szlachecki ideał był w tym czasie nie tyle wymarzony, ile nieosiągalny. A jednak władze austriackie dawały nadzieję na podniesienie społecznej pozycji. Musiał minąć długi czas, aby ruskie elity w Galicji, słabo zorientowane w prawdziwych celach przeprowadzanych przez Habsburgów reform oświeceniowych, pozbyły się kuszącej iluzji, że istnieje możliwość zupełnego dorównania wyższym warstwom społecznym, których życie tradycyjnie obracało się w kręgu polskiej, niemieckiej i łacińskiej kultury.

Ten właśnie dylemat - stać na stanowisku arystokratycznym czy demokratycznym? - najwyraźniej ujawnił się w środowisku duchowieństwa greckokatolickiego, pełniącego wśród ruskiej wspólnoty w Galicji (zwłaszcza w pierwszej połowie XIX w.) funkcję politycznej elity. Podwyższenie w wyniku reform terezjańsko-józefińskich społecznej pozycji duchowieństwa greckokatolickiego i przekształcenie duchownych siłą rzeczy w politycznych działaczy - a to wszystko na tle ciągłych materialnych trudności - uczyniło duchowieństwo greckokatolickie mniej odpornym na pokusę dorównania polskiej szlachcie. Jak pisał później historyk Mychajło Zubryćkyj, „żeby zetrzeć hańbę przynależności do ciemnej, pokrzywdzonej masy ruskiego chłopstwa, [duchowni] wyrzekali się wszelkiego związku ze swoim narodem i na siłę wpychali się do polskiego towarzystwa"26. Naśladowane przez greckokatolickie duchowieństwo szlacheckie wzorce cechowały się zazwyczaj niskim poziomem, a w stosunku do chłopstwa księża uniccy występowali przeważnie z paternalistycznej pozycji. Nawet później - już w drugiej połowie XIX wieku - greckokatolickie duchowieństwo w Galicji było zorganizowane na wzór klanów; stanowiło ono warstwę prawie hermetyczną, której poziom życia i zachowanie przypominały raczej egzystencję drobnej polskiej szlachty.

Pretendowanie greckokatolickiego duchowieństwa do zajmowania uprzywilejowanej pozycji w ruskim społeczeństwie stało się jedną z podstawowych przesłanek ruchu rusofilskiego („moskalofilskiego”). Akcentując swoją „uczoność” (w istocie często ograniczoną do słabej znajomości języka cerkiewnosłowiańskiego), duchowni ci pragnęli podkreślić swą wyższość nad ludem. Po raz pierwszy owa tendencja ujawniła się podczas tak zwanego zjazdu ruskich uczonych w październiku 1848 roku. $\mathrm{W}$ ten sposób rusofile, aby zachować swoją pozycję społeczną i polityczną, będą

26 М. Зубрицький, Причинки до історії руського духовенства в Галичинї від 1820-1853 p. [w:] idem, Зібрані твори і матеріали у 3 m., відп. ред. Ф. Сисин, т. 1: Наукові праціі, Львів 2013, s. 517. 
w rywalizacji z elitami ludowymi odwoływać się właśnie do „uczoności”27. Pragnienie kulturowych więzi z Rosją oraz nadzieje na obronę przed Polakami przez rząd rosyjski w świadomości galicyjskich rusofilów łączyły się z monarchicznymi sympatiami - deklaracjami politycznej lojalności wobec monarchii habsburskiej. Niemiecka badaczka Anna Veronika Wendland w ogóle postrzega rusofilów jako przede wszystkim konserwatystów ${ }^{28}$.

Narodowcy (ukrainofile) po przekształceniu się w siłę polityczną nie uniknęli pokusy chęci dorównania polskim konserwatystom. Nastroje takie pojawiły się po „nowej erze” z 1890 roku - porozumieniu z przedstawicielami austriackich państwowych i krajowych polskich władz, którego ceną było zerwanie narodowców ze zwolennikami orientacji rusofilskiej („moskalofilskiej”). Ugoda doprowadziła do rozłamu środowiska narodowców na dwie konkurujące grupy - zwolenników (Ołeksandr Barwinśkyj) i przeciwników (Julijan Romanczuk) ugody z Polakami. Prócz tego narodowcy zdobyli bezkompromisowych oponentów w postaci rusofilów („moskalofilów”) oraz radykałów ${ }^{29}$, których pozycja rosła i którzy przyciągali do siebie młodzież z obozu narodowców. Sytuacja ta wymagała nowej organizacyjnej struktury. Ostre polityczne dyskusje z lat 90. XIX wieku doprowadziły do utworzenia w Galicji nowoczesnych ukraińskich partii. Zdecydowana większość narodowców kontynuowała swoją działalność w Ukraińskiej Partii Narodowo-Demokratycznej, utworzonej w 1899 roku. Zwolennicy porozumienia z Polakami (stronnictwo Ołeksandra Barwinśkiego) zapoczątkowali zaś w ruchu ukraińskim w Galicji konserwatywny nurt chrześcijańsko-społeczny.

Studia nad ukraińskim konserwatyzmem w Galicji są dopiero w początkowej fa$z_{i e}^{30}$. Wstępnie można jedynie stwierdzić, że mimo zachowawczej retoryki w rzeczywistości ów ruch miał przeważnie na celu zrujnowanie, a nie zachowanie starego układu. Wynikało to z konfliktu między wzrastającym poziomem narodowej świadomości i organizacji rusko-ukraińskiej wspólnoty z jednej strony, a polską autonomią z drugiej. Ten konflikt, będąc głównym bodźcem rozwoju ukraińskiego ruchu w Galicji, nie zostawiał ukraińskim elitom politycznym nic innego do wyboru, jak dążyć do złamania systemu polskiej dominacji w ramach galicyjskiej autonomii. Na początku XX wieku liberalne, nacjonalistyczne, socjalistyczne i inne radykalne idee sekularyzowały polityczną przestrzeń Galicji, wciągały w politykę wszystkie warstwy społeczne, podawały w wątpliwość autorytet i osiągnięcia poprzednich pokoleń działaczy politycznych. Ukraiński nurt konserwatywny - reprezentowany na początku XX wieku przez odłam rusofilów („starokursników”), chrześcijańskich

27 О. Аркуша, М. Мудрий, Русофільство в Галичині в середині XIX-на початку XX cm. Генеза, етапи розвитку, світогляд, „Вісник Львівського університету. Серія історична” 1999 , вип. 34, s. 231-268.

28 А.В. Вендланд, op. cit.

29 W 1890 r. została utworzona Rusko-Ukraińska Partia Radykalna. Szerzej zob. R. Tomczyk, Galicyjska Rusko-Ukraińska Partia Radykalna w latach 1890-1914, Szczecin 2007.

${ }_{30}$ Niektóre zadania badawcze w tym kierunku omówiono w: Р. Лехнюк, Украӥнські консервативні середовища в ідейному просторі Львова початку ХХ століття [w:] Львів. Місто - суспільство - культура. 3б. наук. праць, т. 10: Львів/Lwów/Lemberg як міські простори. Уявлення, досвіди, практики, ред. О. Аркуша, О. Вінниченко, М. Мудрий, ч. 1, Львів 2016, s. 310-345. 
społeczników (grupę Ołeksandra Barwinśkiego dążącą do porozumienia z Polakami) i Cerkiew greckokatolicką (na czele z metropolitą Andrzejem Szeptyckim) - nie miał platformy ideowej; był przede wszystkim zjawiskiem społecznym: przeciwstawiał się rozpowszechnionym w przeddzień I wojny światowej politycznym praktykom nieposzanowania starszych pokoleń (albo ogólnie „człowieka XIX w.”) i radykalizacji nastrojów.

\section{WNIOSKI KOŃCOWE}

Polityczna elita zawsze występuje jako siła zorganizowana, i tym właśnie można wyjaśnić jej władzę nad większością. Ruskie elity polityczne w Galicji w ciągu XIX wieku stopniowo ewoluowały od środowisk „zamkniętych” (bardzo powoli rozwijających się, z ograniczoną ruchliwością i podporządkowaniem się decyzjom ograniczonego grona osób) do stosunkowo „otwartych” (dopuszczających spontaniczne wejście nowych członków w wyniku wyborów lub politycznych kompromisów). Priorytetowymi wartościami tych ostatnich stawały się: profesjonalizm, a w pewnym zakresie działania i reputacja publiczna reprezentanta elity.

Cechą charakterystyczną XIX-wiecznych ruskich/ukraińskich elit politycznych w Galicji było przeplatanie się politycznych, gospodarczych, duchowo-intelektualnych i naukowych środowisk. Wyjaśnić to można niepełnością socjalnej struktury ówczesnego ruskiego społeczeństwa w Galicji. W tym sensie tożsamość rusko-ukraińskich elit była nieodłącznym skutkiem trwającego wówczas procesu modernizacji społecznej. W pewnym sensie politykiem stawał się każdy, kto zdobył wyższy poziom wykształcenia; oświata już sama przez się stawiała przed człowiekiem pytanie o jego tożsamość.

Głównym środkiem kształtowania ruskich elit politycznych w Galicji było zideologizowanie etniczności. W poszukiwaniu harmonii między układem racjonalnym (rzeczywistością w tym czasie były imperia) i światem wewnętrznym człowieka (stającego się obywatelem) oraz znalazłszy się na przecięciu austriackich, polskich i rosyjskich interesów, „wykształceni Rusini” w Galicji wahali się między austrofilstwem, polonofilstwem, rusofilstwem, ukrainofilstwem. I tylko demokratyzacja życia społecznego na przełomie XIX i XX wieku przesądziła o zdobyciu przewagi przez wariant ukraińskiej tożsamości wśród ruskiej ludności na prowincji.

Ruskie elity polityczne w Galicji definiowały swoją tożsamość nie tylko na polu narodowym, ale również społecznym. Wyraźnie ujawniały się różnice między pokoleniami ruskich elit politycznych. Na pierwszy rzut oka wyglądają one (i tak też zostały opisane w historiografii) jako obmyślony i uzasadniony ruch w kierunku tożsamości ukraińskiej. Koniunkturalne podteksty takiego wyjaśnienia można zrozumieć. Należy jednak mieć na uwadze, że każde powstanie i przejaw rusko-ukraińskich counter-elit, które stymulowały modernizację społeczeństwa, miało w XIX wieku zarówno ideologiczne narodowe, jak i pokoleniowe przyczyny, czyli było powiązane w pewnym sensie $\mathrm{z}$ kwestionowaniem przez młodych autorytetu starszego pokolenia. 
Historia ruskich/ukraińskich elit politycznych w Galicji łączy się z historią inteligencji. W sytuacji, kiedy stanowiska urzędowe były dla galicyjskich Rusinów trudno dostępne, głównym sposobem kształtowania się ukraińskich elit stała się działalność publiczna. Formowanie się inteligencji jako nowej warstwy społeczeństwa, przyjmującej na siebie obowiązek „służenia narodowi”, już samo przez się było procesem politycznym; inteligencja sprzyjała emancypacji społeczeństwa i rozszerzała społeczną bazę dla polityki. Często obmyślała politykę i sama występowała w roli polityków.

Doświadczanie przez ukraińskie elity polityczne licznych problemów (jak prześladowanie ukraińskiego ruchu w Imperium Rosyjskim, mała liczebność, bardzo ograniczone środki materialne i in.) skutkowało specyficznym rozumieniem przez ukraińskich polityków zagadnienia odpowiedzialności. Punktem oparcia dla nich stawały się nastroje społeczeństwa, a wykraczająca poza granice monarchii habsburskiej narodowa tożsamość łączyła się z dążeniem do zwalczania działających pod kontrolą Polaków galicyjskich instytucji władzy. Dylemat między chęcią złamania systemu rządów krajowych a niekwestionowaną lojalnością wobec Wiednia stał się na początku XX wieku dla ukraińskich elit politycznych w kraju wyzwaniem bardzo trudnym do rozwiązania.

Kwestia tożsamości wśród ruskich/ukraińskich politycznych elit w Galicji miała też zewnętrzny wymiar, czyli w dużym stopniu zależała od działań polskich środowisk politycznych, wiedeńskiej koniunktury politycznej, a także ukraińskiego ruchu w Imperium Rosyjskim. Ukraińscy politycy galicyjscy, mimo ostrych polemik na zewnętrz, w rzeczywistości bardzo potrzebowali zewnętrznej uwagi, która była im potrzebna do sformułowania własnych argumentów; wykorzystywali ją w poszukiwaniach ideowych i na jej podstawie tworzyli symbole oraz wyobrażenia składające się na poczucie narodowej odrębności.

\section{BIBLIOGRAFIA}

\section{I. Źródła}

\section{1. Źródła archiwalne}

Центральний державний історичний архів України - м. Львів:

ф. 196: Політичне товариство „Руська рада”, оп. 1, спр. 18, арк. 1-4 (Memoriał pt. Mысcли для согласного поступованя галищкихъ Русиновъ въ дюлахъ своихъ народныхъ, 28 XII 1870).

\section{2. Źródła drukowane}

Podoliński B., Słowo przestrogi [1848 r.], вид. Ф. Стеблій, „Записки Наукового товариства імені Шевченка" (Львів) 1994, т. 228: Праці Історично-філософської секції, s. 444-462. 
[Барвінський В.], Въ стольтниि роковины вступленя на австрійскій престоль ицгсаря Іосифа II (1780-1880). Отчить Володимира Барвъньского, выголошеный на вечерг дня 17 (29) листопада 1880, Львів 1880.

\section{Prasa}

[І. Наумович] Одинъ именемъ многихъ, Отъ Львова. Поглядъ въ будучность, „Слово" 1866, nr 59 z 27 VII (8 VIII).

Оิтозва до руского народу [10 V 1848], „Зоря Галицка” 1848, nr 1 z 15 V.

\section{Opracowania}

Adamski Ł., Nacjonalista postępowy. Mychajło Hruszewski i jego poglądy na Polskę i Polaków, Warszawa 2011.

Arkusza O., Ukraińskie przedstawicielstwo w sejmie galicyjskim [w:] Ukraińskie tradycje parlamentarne, XIX-XXI wiek, red. J. Moklak, Kraków 2006, s. 13-57.

Binder H., Ukraińskie przedstawicielstwo w austriackiej Izbie Posłów, 1879-1918 [w:] Ukrainskie tradycje parlamentarne, XIX-XXI wiek, red. J. Moklak, Kraków 2006, s. 127-162.

Himka J.-P., Religion and Nationality in Western Ukraine. The Greek Catholic Church and the Ruthenian National Movement in Galicia 1867-1900, Montreal-Kingston-LondonIthaca 1999.

Himka J.-P., The Construction of Nationality in Galician Rus'. Icarian Flights in Almost All Directions [w:] Intellectuals and the Articulation of the Nation, ed. by R.G. Suny, M.D. Kennedy, Ann Arbor (Mich.) 1999, s. 109-164.

Kozik J., Między reakcją a rewolucją. Studia z dziejów ukraińskiego ruchu narodowego w Galicji w latach 1848-1849, Warszawa-Kraków 1975.

Kozik J., Ukraiński ruch narodowy w Galicji w latach 1830-1848, Kraków 1973.

Maciak D., Próba porozumienia polsko-ukraińskiego w Galicji w latach 1888-1895, Warszawa 2006.

Moklak J., Hałyczyna contra Galicja. Ukraińskie szkolnictwo średnie i wyższe w debatach Sejmu Krajowego galicyjskiego 1907-1914, Kraków 2013.

Moklak J., W walce o tożsamość Ukrainców. Zagadnienia języka wykładowego w szkotach ludowych i średnich w pracach galicyjskiego Sejmu Krajowego 1866-1892, Kraków 2004.

Mudryj M., Formacja gente Rutheni, natione Poloni w XIX-wiecznej Galicji a pojęcie ojczyzny [w:] Formuly patriotyzmu w Europie Wschodniej i Środkowej od nowożytności do wspótczesności, red. A. Nowak, A.A. Zięba, Kraków 2009, s. 285-298.

Nabywaniec S., Antoni Angetlowicz i Michat Lewicki, pierwsi greckokatoliccy metropolici halicko-lwowscy, „Resovia sacra. Studia Teologiczno-Filozoficzne Diecezji Rzeszowskiej” (Rzeszów) 1996, t. 3, s. 139-157.

Osadczy W., Święta Ruś. Rozwój i oddziaływanie idei prawosławia w Galicji, Lublin 2007. Pijaj S., Posłowie ruscy w parlamencie wiedeńskim [w:] Ukraińskie tradycje parlamentarne, XIX-XXI wiek, red. J. Moklak, Kraków 2006, s. 95-126.

Sroka Ł.T., Rada Miejska we Lwowie w okresie autonomii galicyjskiej 1870-1914. Studium o elicie władzy, Kraków 2012. 
Świątek A., Gente Rutheni, natione Poloni. Z dziejów Rusinów narodowości polskiej w Galicji, Kraków 2014.

Tomczyk R., Galicyjska Rusko-Ukraińska Partia Radykalna w latach 1890-1914, Szczecin 2007.

Wołczański J. ks., Wydział Teologiczny Uniwersytetu Lwowskiego w latach 1661-1939 [w:] Universitati Leopoliensi. Trecentesimum quinquagesimum anniversarium suae fundationis celebranti. In memoriam, red. W. Lohman, Kraków 2011, s. 77-144.

Wójtowicz-Huber B., ,, Ojcowie narodu”. Duchowieństwo greckokatolickie w ruchu narodowym Rusinów galicyjskich (1867-1918), Warszawa 2008.

Аркуша О., ,Нова ера” [w:] Енициклопедія історї України, т. 7, Київ 2010, s. 427-430. Аркуша О., Мудрий М., Русофільство в Галичині в середині XIX-на початку XX cm. Генеза, етапи розвитку, світогляд, „Вісник Львівського університету. Серія історична" 1999, вип. 34, s. 231-268.

Вендланд А.В., Русофіли Галичини. Украӥнські консерватори між Австрією та Роciєю, 1848-1915, пер. 3 нім. Х. Назаркевич, наук. ред. М. Мудрий, Львів 2015.

Гайндль В., Модернізація та теорії модернізації. Приклад габсбурзької бюрократії, „Україна модерна” 1996, ч. 1, s. 89-100.

Грицак Я., Українське національне відродження в Галичині XIX - початку XX cm. Порівняльний аналіз сочіального складу патріотичних груп, „Krakowskie Zeszyty Ukrainoznawcze" 1996-1997, t. 5-6, s. 277-285.

Зубрицький М., Причинки до історї руського духовенства в Галичинї від 1820 1853 p. [w:] М. Зубрицький, Зібрані твори і матеріали у 3 m., відп. ред. Ф. Сисин, т. 1: Наукові праці, Львів 2013, s. 516-541.

Касьянов Г., Теорії нації та націоналізму, Київ 1999.

Киричук О., Львівський Ставропігійський інститут у громадському житті Галичини другої половини XIX-початку XX ст., Львів 2001.

Лехнюк Р., Українські консервативні середовища в ідейному просторі Львова початку ХХ століття [w:] Львів. Місто - суспільство - культура. Зб. наук. праць, т. 10: Львів/Lwów/Lemberg як міські простори. Уявлення, досвіди, практики, за ред. О. Аркуша, О. Вінниченко, М. Мудрий, ч. 1, Львів 2016, s. 310-345.

Лисяк-Рудницький I., Українці в Галичині під австрійським пануванням [w:] I. Лисяк-Рудницький, Iсторичні есе, упоряд. Я. Грицак, т. 1, Київ 1994, s. $413-$ 450.

Монолатій І., Інші свої. Політична участь етнічних акторів пізньогабсбурзьких Галичини і Буковини, Івано-Франківськ 2012.

Монолатій I., Разом, але майже окремо. Взаємодія етнополітичних акторів на західноукраїнських землях у 1867-1914 рр., Івано-Франківськ 2010.

Мудрий М., Австрорусинство в Галичині. Спроба окреслення проблеми, „Вісник Львівського університету. Серія історична” 2000, вип. 35-36, s. 571-604.

Мудрий М., Ідеологія чи світогляд? До питання про теоретичні засади Руського Собору 1848 року, „Вісник Львівського університету. Серія історична” 2009, вип. 44, s. $75-106$.

Орлевич I., Ставропігійський інститут у Львові (кінець XVIII - 60-і рp. XIX cm.), Львів 2001 [2-ге вид.].

Пахолків С., Украйнська інтелітенція у Габсбурзькій Галичині. Освічена верства й емансипація нації, Львів 2014.

Плохій С., Великий переділ. Незвичайна історія Михайла Грушевського, Київ 2011. 
Райківський І., Ідея украӥнської начіональної єдності в громадському житті Галичини ХІХ століття, Івано-Франківськ 2012.

Сіромська Г., Народний Дім у Львові: від старорусинства до русофільства (середина XIX-початок XX cm.), Львів 2014.

Сухий О., Від русофільства до москвофільства (російський чинник у громадській думці та суспільно-політичному житті галицьких українців у XIX столітті), Львів 2003.

Тельвак В., Педич В., Львівська історична школа Михайла Грушевського, Львів 2016.

[Терлецький О.], Галицько-руське письменство 1848-1865 рр. на тлї тогочасних суспільно-полїтичих змагань галицько-руської інтелїгениї. Недокінчена праця Д-ра Остапа Терлеиького, переднє слово І. Франко, Львів 1903.

Турій О., Греко-католищька Церква і револючія 1848-1849 pp. у Галичині [w:] Rok 1848. Wiosna Ludów w Galicji, red. W. Wic, Kraków 1999, s. 72-91.

Химка I., „Апологія” Михайла Малиновського. До історії кризи у греко-католицькій церкві 1882 року і характеристики поглядів „,святоюриів”, „Записки Наукового товариства імені Шевченка” 1993, т. 225: Праці Історично-філософської секиії, s. $365-392$.

Чорновол І., Польсько-українська угода 1890-1894 рp., Львів 2000.

Чорновол I., 199 депутатів Галицького сейму, Львів 2010.

Янишин Б., Українська міська політична еліта в Галичині та народовський рух останньої третини XIX cm. Становлення та інституційний розвиток, Київ 2008. 